\title{
The Legality of Parking Meter Ordinances and Permissible Use of Parking Meter Funds
}

\section{Marion Allen Grimes*}

$\mathrm{O}$

NE of the most critical problems facing cities today is that of proper traffic control and regulation. Because of the enormous increase in the number of registered motor vehicles within California, its cities have been particularly vexed. The growth of vehicular traffic during the last decade throughout America caused most cities to enact ordinances regulating the length of time for parking in a given space. Practical enforcement of such regulations not only met with difficulty but also failed to furnish anticipated results. In 1936 the municipal authorities of Oklahoma City turned to the parking meter, hopeful of finding a solution to the downtown parking problem. Experience since that time has indicated that the parking meter is no panacea but is, nevertheless, a useful device greatly facilitating efficient traffic control and regulation.

The primary purpose of the parking meter is to regulate auto parking in otherwise congested areas. A secondary but nonetheless important purpose is to provide necessary revenues to finance an adequate traffic control program. ${ }^{2}$ In the eleven years since their first

*A.B. University of California at Los Angeles, 1937 ; LL.B. University of California, 1946; Assistant Legal Counsel, League of California Cities.

In 1935 there were 2,255,000 registered motor vehicles. By 1946 thare had been a gain of approximately fifty-three per cent, the number of registrations having swelled to $3,442,000$. On the basis of a population of $12,200,000$ by 1960 , it has been estimated that the number of registered inotor vehicles in Cabifornia will amount to $5,200,000$.

2 Parking Meters; Their Use for Traffic Control and Revenue (Municipal Fimance Officers Association, Special Bulletin 1946F, March, 1946); Kennedy, Traffic and Parking (Sept., 1946) 22 WESTERN CITY 24. For general discussion of the use of parking meters see The Parking Problem (Eno Foundation for Traffic Control, Inc., 1942); Traffic and Parking Study (New York Regional Plan Association, Inc., Dec., 1942); Automobile Parking in Central Business Districts (Urban Land Institute, July, 1946); Brown, Effective Control by Parking Meters (Aug., 1937) 52 Adarerican Crry 53; Corbett, 75 Cities Report on Parking Meters (March, 1941) 56 ibid. 71; Cities Seek Solutions for New Parking Problem (1945) 34 National MUNCTPal Rev. 570; Bearce, The Bureau of Standards Looks at Parking Meters (1938) 15 VA. MUNICTPA Rev. 196; Mosier, Parking Meters-What They Are and How They Work (Dec., 1935) 11 WESTERN CITY 34. 
installation, at least 491 cities in the United States have installed parking meters. ${ }^{3}$ Seventy-two California cities have approved the installation of parking meters at the present time. ${ }^{4}$ As is so often the case of any new development, the constitutional validity of the ordinances providing for the parking meter has been questioned. ${ }^{5}$

\section{I.}

\section{LEGALITY OF PARKING METER ORDINANCES IN GENERAL}

The parking meter ordinances have been subjected basically to two attacks: (1) lack of the requisite delegated authority in a munnicipality to enact such ordinances; (2) the illegal exercise of such an authority concededly delegated. ${ }^{6}$ It is a well-established rule of municipal law that a municipal corporation possesses and can exercise only those powers expressly granted to it, those necessarily or fairly implied im or incident to the powers expressly granted, and those essential to the accomplishment of the declared objects and purposes of the corporation, not sinply convenient but indispensable. When no such power has been granted the municipality, the cases have been clear in holding the parking meter ordinance invalid. ${ }^{8}$

3 The Municipar Year Book (1946) 461.

4 Alameda, Anaheim, Arcata, Auburn, Blythe, Burbank, Burlingame, Calistoga, Coronado, Covina, Crescent City, Culver City, Dunsmuir, El Centro, El Cerrito, El Monte, Eureka, Fairfield, Fresno, Fullerton, Hayward, Healdsburg, Hemet, Hermosa Beach, Huntington Beach, Huntington Park, Indio, Inglewood, Laguna Beach, La Mesa, Long Beach, Los Banos, Marysville, Merced, Modesto, Napa, National City, Newport Beach, Oakland, Ontario, Oroville, Palo Alto, Placerville, Pomona, Redondo Beach, Redwood City, Richmond, Riverside, Roseville, Sacramento, St. Helena, Salinas, San Bernardino, San Diego, San Fernando, San Francisco, San Jose, San Mateo, San Rafael, Santa Ana, Santa Cruz, Santa Rosa, Sebastopol, Sonora, So. San Francisco, Stockton, Turlock, Ukiah, Vallejo, Walnut Creek, Watsonville, Whittier.

5 State v. McCarthy (1936) 126 Fla. 433, 171 So. 314. The validity of parking meters las been discussed in the following legal periodicals: Conrad and Aberg, Validity of Parking Meter Ordinances (1943) 29 VA. L. Rev. 617; Notes (1937) 22 Iowa L. REv 713 ; (1938) OHTo ST. L. J. 198; (1938) 17 ORE. L. REv. 126; (1940) 4 UnIV. S. C SeIdeN Soc. Year Book 22; (1941) 29 CaLIF. L. Rev. 651; (1937) 15 ChI-KeNT Rev. 249; (1939) 8 GEo. WASH. L. REv. 237; (1943) 31 ILL BAR J. 218; (1939) 14 IND. L. J. 553; (1943) 18 ibid. 324; (1937) 36 MxcH. L. Rev. 157; (1939) 37 ibid. 498; (1945) 21 NOtre Dame LaW. 58; (1939) 3 U. Det. L. J. 42 ; (1941) 4 ibid. 120.

6 Note (1941) 130 A. L. R. 316.

7 I DILION, Municipar Corporations (5th ed. 1911) §237. The rule has received judicial recogmition in California. West Coast Adver. Co. v. San Francisco (1939) 14 Cal. (2d) 516,95 P. (2d) 138. It is to be noted, lowever, that freeliolders' charter cities which have accepted the tender of the 1914 amendment to section 6 of article XI of the California constitution possess an express grant of plenary authority over "municipal affairs".

8 City of Shreveport v. Brister (1939) 194 La. 615, 194 So. 566; Monsour v. City of Slureveport (1940) 194 La. 625, 194 So. 569; Rhodes v. Raleigh (1940) 217 N. C. 627, 
When the exercise of a delegated power has been challenged as improper three major issues have been discussed. They are: (1) whether the installation of parking meters to regulate the use of the public streets is a reasonable exercise of the police power conferred by the legislature on a city; (2) whether the physical presence of the parking meters in front of premises of an abutting property owner constitutes an unreasonable interference with his property rights; (3) whether the installation of parking meters and the attendant collection of a fee is actually a regulatory and not a revenue measure.

\section{Exercise of police power.}

The great weight of authority has upheld the use of parking meters as a reasonable regulation of traffic by a city in order to provide for the public welfare. ${ }^{9}$ The rationale supporting this conclusion is clearly stated in State v. McCarthy: ${ }^{10}$

"The individual's ordinary right as a member of the public to the free use of a city's streets in the normal pursuit of his private business or personal pleasure must sometimes yield to the paramount rights and necessities of the general public. This right of the individual cannot be taken from him, but it is subject to regulation in the interest of the public good."

\footnotetext{
9 S.E. (2d) 389 , (1941) 130 A. L. R. 311 ; In re Opinion to the House of Representatives (1939) 62 R.I. 347, 5 A. (2d) 455; Note (1941) 130 A. L. R. 316.

9 City of Phoenix v. Moore (1941) 57 Ariz. 350, 113 P. (2d) 935; Hughes v. City of Phoenix (1946) ........ Ariz. ........, 170 P. (2d) 297; State v. McCarthy, supra note 5; Foster's Inc. v. Boise City (1941) 63 Idaho 201, 118 P. (2d) 721; City of Bloomington v. Wirrick (1943) 381 Ill. 347, 45 N.E. (2d) 852, cert. den., (1943) 319 U.S. 756; Andrews v. City of Marion (1943) 221 Ind. 422,47 N. E. (2d) 968 ; City of Louisville v. Louisville Automobile Club (1942) $290 \mathrm{Ky}, 241,160 \mathrm{~S}$. W. (2d) 663 ; In re Opinion of Justices (1937) 297 Mass. 559, 8 N. E. (2d) 179; Bowers v. City of Muskegon (1943) 305 Mich. 676, 9 N.W. (2d) 889; Hendricks v. City of Minneapolis (1940) 207 Minn. 151, 290 N.W. 428; Wilhoit v. City of Springfield (1943) 237 Mo. App. 775, 171 S. W. (2d) 95 ; State v. City of Mexico (1946) ....... Mo. ......., 197 S.W. (2d) 301; Opinion of the Justices (1947) ....... N. H. ......., 51 A. (2d) 836; Gilsey Buildings, Inc. v. Village of Great Neck Plaza (1939) 170 Misc. 945, 11 N. Y.S. (2d) 694, aff'd., (1939) 258 App. Div. 901, 16 N.Y.S. (2d) 832; City of Columbus v. Ward (1940) 65 Ohio App. 522, 31 N.E. (2d) 142; Turnbull v. City of Xemia, (1946 ....... Ohio App. ......., 69 N. E. (2d) 378; Ex parte Duncan (1936) 179 Okla. 355, 65 P. (2d) 1015; Hickey v. Riley (1945) 177 Ore. 321, 162 P. (2d) 371; Morris v. City of Salem (1946) ...... Ore. ......, 174 P. (2d) 192; Clark v. City of New Castle et al. (1938) $32 \mathrm{~Pa}$. D.\& C. 371; William Laubach \& Sons v. Easton (1943) 347 Pa. 542, 32 A. (2d) 881; Owens v. Owens (1940) 193 S. C. 260, 8 S. E. (2d) 339; Harper v. City of Wichita Falls (Tex. Civ. App. 1937) 105 S. W. (2d) 743; Exc parte Harrison (1938) 135 Tex Crim. App. 611, 122 S.W. (2d) 314; City of Galveston v. Galveston County (Tex. Civ. App 1942) 159 S. W. (2d) 976; Kimmel v. Spokane (1941) 7 Wash. (2d) 372, 109 P. (2d) 1069; County Court v. Roman (1939) 121 W. Va. 381, 3 S. E. (2d) 631; Note (1941) 130 A. L. R. 316.

10 Supra note 5 , at 437,171 So. at 315 .
} 
A few jurisdictions have declared parking meter ordinances invalid. ${ }^{11}$ In several the court came to the conclusion that the municipality had not been granted the power to regulate traffic by use of parking meters. ${ }^{12}$ The ordinance in one jurisdiction was held bad as levying a license fee, such fees being prohibited by the state law..$^{13}$ Another jurisdiction held that a city which had power to pass a parking meter ordinance had wrongly exercised that power since the measure was for revenue rather than regulation. ${ }^{14}$ Another ordinance was held invalid as not being a proper exercise of the police power, since it violated the rights of an abutting property owner. ${ }^{15}$

\section{Rights of abutting property owners.}

Often pressed, but only once sustained, is the argument that the installation of parking ineters on the curb of a public street violates the common-law rights of abutting property owners. ${ }^{16}$ It is generally said that the property which an abutting owner has in the street in front of his land is the right of access, and the right to light and air. ${ }^{17}$ The majority of cases considering this argument have concluded that the easement of access is subject to reasonable regulation in the interest of the public good. ${ }^{18}$ In the only contrary decision, ${ }^{10}$ the court placed its holding on three grounds: the ordinance was not a proper exercise of the police power but an imposition of an indirect tax without proper authorization; parking meters constituted illegal nuisances as a matter of law; the installation of parking meters was a violation of due process by depriving abutting owners of a lawful right in op-

11 City of Birmingham v. Hood-McPherson Realty Co. (1937) 233 Ala. 352, 172 So. 114; Brodkey v. Sioux City (1940) 229 Iowa 1291, 291 N. W. 171; cases cited in note 8, supra.

12 City of Shreveport v. Brister; Monsour v. Gity of Shreveport; In re Opinion to the House of Representatives, all sulpra note 8.

13 City of Shreveport. v. Brister; Monsour v. City of Shreveport, both supra note 8.

14 Rhodes v. Raleigh, supra note 8.

15 City of Birmingham v. Hood-McPherson Realty Company, supra note 11.

16 Ibid.

174 MCQuitus, Munictpal Corporattons (2d ed. 1943) § 1425.

18 State v. McCarthy; Foster's, Inc. v. Boise City; Andrews v. City of Marion; City of Louisville v. Louisville Automobile Club; In re Opinion of Justices; Hendricks v. City of Minneapolis; Wilhoit v. City of Springfield; Gilsey Buildings, Inc. v. Village of Great Neck Plaza; City of Columbus v. Ward; Hickey v. Riley; Clark v. City of New Castle et al.; William Laubach \& Sons v. Easton; Owens v. Owens; Ex parte Har. rison; Kimmel v. Spokane; County Court v. Roman, all supra note 9.

10 City of Birmingham v. Hood-McPherson Realty Co., supra note 11. 
position to the terms of an instrument dedicating to the city the land for the street. The court said:

"The right of access includes passage, accessibility, and stopping briefly and reasonably in front of premises without unnecessarily inconveniencing the passage of the general public. ... The owner has the right to come and go, and park his vehicle alongside of his property (within reasonable limitations), without the exaction or payment of a tax or fee to the municipality, or to have his property defaced by superimposed obstructions, barriers, or parking ineters placed alongside." 20

Most courts have distinguished this holding as turning on the peculiar terms of the instrument of dedication. ${ }^{21}$ The subsequent cases illustrate that the rights of the abutting property owners have taken a subordinate position to the public right to adequate parking. ${ }^{22}$

\section{Revenue versus regulation.}

It is black letter law that a municipality may not impose an otherwise unauthorized revenue tax under the guise of a police regula. tion. ${ }^{23}$ This principle has been used to challenge the validity of parking meters. ${ }^{24}$ Although this argument has been advanced often, only once has it been successful. ${ }^{25} \mathrm{~A}$ inunicipality may validly install a system of parking meters upon its streets and exact a fee for parking as long as the amount charged bears a reasonable relation to the service rendered and the cost of rendering it. The courts have been practical in deciding what constitutes a reasonable relation between the fee and the service. The distinction between the taxing and the police power is to be found in the purpose for which the particular power is exercised..$^{26}$ Courts have insisted that it nuust be made plain

20 Ibid. at 362,172 So. at 123.

21 Hickey v. Riley; Ex parte Harrison, both supra note 9.

22 Cases cited in note 18 , supra.

234 CoOLEX, TaXatron (4th ed. 1924) \& 1680.

24 City of Shreveport v. Brister; Monsour v. City of Shreveport; Rhodes v. Raleigh, all supra note 8; City of Phoenix v. Moore; State v. McCarthy; Foster's, Inc. v. Boise City; City of Bloomington v. Wirrick; Andrews v. City of Marion; City of Louisville v. Louisville Automobile Club; In re Opinion of Justices; Bowers v. City of Muskegon; Hendricks v. City of Minneapolis; Wilhoit v. City of Springfield; Ex parte Duncan; Hickey v. Riley; Clark v. City of New Castle et al.; William Laubach \& Sons v. Easton; Owens v. Owens; Harper v. City of Wichita Falls; Ex parte Harrison; Kimunel v. Spokane; County Court v. Roman, all supra note 9; City of Birmingham v. Hood-McPherson Realty Co.; Brodkey v. Sioux City, both supra note 11.

25 Brodkey v. Sioux City, supra note 11 .

23 Hendricks v. City of Minneapolis; Hickey v. Riley; William Laubach \& Sons v. Easton, all supra note 9. 
that the scheme of the ordinance is such that the receipts will continuously and by a substantial amount exceed the cost of installation, maintenance and regulation of traffic in order for the ordinance to be declared invalid.

The Idaho court puts it as follows:

\begin{abstract}
"The means and instrumentalities, by and through which the supervising powers of the policing authority are brought to bear on the subject to be regulated, involve costs and expenses. It is only reasonable and fair to require the business, traffic, act, or thing that necessitates policing, to pay this expense. To do so has uniformly been upheld by the courts. On the other hand, this power may not be resorted to as a shield or subterfuge, under which to enact and enforce a revenue-raising ordinance or statute. . . . The fact that the fees charged produce more than the actual cost and expense of the enforcement and supervision, is not an adequate objection to the exaction of the fees. The cliarge made, however, must bear a reasonable relation to the thing to be accomplished." $2 \pi$
\end{abstract}

In determining whether a particular ordinance is a regulatory or revenue measure, it has often been said that a declaration in the ordinance as to its purpose is both relevant and persuasive although not conclusive. ${ }^{28}$ Draftsmen of parking meter ordimances might well take cognizance of this fact. Courts will not look behind the regulatory purpose expressed in a statute in the absence of evidence tending to show that the declaration is a sham and that the ordinance is really a revenue measure.

The use to which the funds acquired as regulatory fees may be applied is a question of practical importance to municipal officers. In Hickey $v$. Riley the proper uses of these funds which are possible were detailed as follows:

"Traffic controls include traffic signals, safety islands, street marking to direct traffic, tunnels for pedestrian use under dangerous intersections, the salaries of police officers engaged in policing parking meters and investigating traffic accidents, purchase of automobiles and other necessary equipment for the use of such officers, and the expense of remodeling the police station to provide facilities for landling cases of violation of traffic regulations.... The expenditure

$2 \pi$ Foster's, Inc. v. Boise City, supra note 9, at 218, 118 P. (2d) at 728. Cf. Coodex, TAXation (4th ed. 1924) \$1680.

28 City of Phoenix v. Moore; Hendricks v. City of Minneapolis; Wilhoit v. City of Springfield; William Laubach \& Sons v. Easton, all supra note 9. 
of the meter revenues for such purposes ... is reasonably within the general purpose of traffic control." 29

The burden of proving that a parking meter ordinance is a revenue rather than a regulatory measure is with the contesting party. ${ }^{30}$ In addition to the usual presumption that an ordinance is valid, it has been said that in determining the validity of a parking meter ordinance as a regulatory measure the ainount of the fee charged should prima facie be accepted as the cost of the service. ${ }^{31}$ In one jurisdiction the court said that if the fees collected through the meter were excessive so as to change the character of the meter from a regulatory to a revenue device, the court had the power to require reduction of the fee so as to remove the objectionable feature. ${ }^{32}$

It would appear that the establishment of a fund for making available off-street parking facilities, thereby furthering the regulation of traffic and the diminution of congestion, constitutes a permissible use of parking meter funds. ${ }^{33}$ Such a use is especially desirable since the establishment of adequate off-street parking facilities often provides the ultimate solution of the traffic problem. A Pennsylvania court has said that the parking meter revenues could be held in a fund to be used to satisfy any future judgments which might be awarded against a municipality because of traffic operations. ${ }^{34}$

In summary then, it may be said that any use of parking meter funds which is substantially related to the over-all problein of traffic regulation and traffic control would be permissible.

\section{Delegation of authority to select meter zones.}

Several parking meter ordinances have delegated the authority for determining the area to be used for installation of parking meters, as well as the specific location of the meters, to a subordinate public official. The ordinance challenged in the $M c$ Carthy case ${ }^{35}$ authorized the city manager to establish such parking meter zones as he might select from time to time as conditions required. In Hendricks v. City of Minneapolis ${ }^{36}$ the location of the meters and the method of instal-

20 Supra note 9, at 336, 162 P. (2d) at 377. Accord: Harper v. City of Wichita Falls, stupra note 9.

30 Wilhoit v. City of Springfield, supra note 9.

31 City of Phoenix v. Moore, supra note 9.

32 City of Louisville v. Louisville Automobile Club, supra note 9.

33 Bowers v. City of Muskegon; Hickey v. Riley, both supra note 9.

34 William Laubach \& Sons v. Easton, supra note 9.

35 Supra note 9.

36 Supra note 9. 
lation were functions given to the city engineer. Both ordinances were held valid. Although a number of parking meter ordinances have delegated the duty of selecting the particular location where the parking meters are to be installed to a subordinate public official, it is of significance that none of these ordinances has been held invalid as an unauthorized delegation of legislative authority.

II.

\section{LEGALITY OF PARIING METERS IN CALIFORNIA}

As an exercise of police power.

To date, there is no decided case in California ruling upon the validity of a parking meter ordinance. In Hodgeman v. City of San Diego $o^{37}$ the court held that a city charter provision requiring competitive bidding did not apply to the purchase of parking ineters. The case of DeAryan v. City of San Diego ${ }^{38}$ involved an action by a taxpayer alleging misuse of funds derived from the operation of parking meters. The court found that the funds were not inaladministered. The legality of the ordinance in question was not attacked. However, the court said, "It has been held that such regulation of parking and control of traffic may well justify a fee system intended and calculated to hasten the departure of parked vehicles in congested areas, as well as to defray the cost of installation and supervision." ${ }^{39}$

Section 11 of article $\mathrm{XI}$ of the state constitution provides:

"Any county, city, town, or township may make and enforce within its limits all such local, police, sanitary, and other regulations as are not in conflict with general laws." 40

Thus, when the validity of a parking meter ordinance is finally considered by the California court, the ordinance should be sustained as a valid exercise of this police power.

The supreme court has held that the power conferred by section 11 of article XI authorizes police regulations by cities on both municipal and state affairs in the absence of conflicting general law. ${ }^{41}$ The power

37 (1942) 53 Cal. App. (2d) 610, 128 P. (2d) 412, hearing den.

38 (July 9, 1946) 75 A. C. A. 347 , 170 P. (2d) 482.

$39 \mathrm{Ibid}$. at $351,170 \mathrm{P} .(2 \mathrm{~d})$ at 485.

40 A similar grant of power is conferred upon all fifth and sixth-class cities organized under the Municipal Corporations Act of 1883 by sections 764(1) and 862(1), respectively, which authorize such cities " ... to pass ordinances not in conflict with the Constitution and laws of this State, or of the United States." Cal. Stats. 1883, pp. 253, 269.

41. Mann v. Scott (1919) 180 Cal. 550, 182 Pac. 281; Ex parle Daniels (1920) 183 Cal. 636, 192 Pac. 442; In re Murphy (1923) 190 Cal. 286, 212 Pac. 30; San Mateo v. 
to regulate motor and other vehicular traffic has been consistently held to be included within section 11 except where in conflict with the Motor Vehicle Code or other general law. ${ }^{42}$ In the absence of such a conflict it follows that a municipality is empowered by section 11 of article XI to regulate parking within its confines for the public safety and welfare. The court in Whyte v. City of Sacramento ${ }^{43}$ said, "It has never been doubted that the local governments of the state, having that power vested in them by the legislature, may establish parking zones in the cities and towns and otherwise regulate the use of the ordinary automobiles." An examination of the Motor Vehicle Code sustains this conclusion. Section 459 authorizes local authorities "within the reasonable exercise of the police power" to regulate traffic by means of traffic officers, semaphores or other traffic control signaling devices. Implicit in section 472 is the conclusion that local authorities may regulate parking on the city streets inasmuch as specific street markings are required whenever local parking regulations are enacted. This viewpoint is substantiated by the court's remark in Pipoly v. Benson ${ }^{44}$ that section 472 empowers local authorities to enact special rules and regulations dealing with the parking of motor vehicles.

A city nuay not, however, enact ordinances which conflict with the provisions of the Motor Vehicle Code. ${ }^{45}$ Thus the stopping, stand-

Railroad Comm. (1937) 9 Cal. (2d) 1, 68 P. (2d) 713; Pipoly v. Benson (1942) 20 Cal. (2d) 366, 125 P. (2d) 482; In re Portney (1942) 21 Cal. (2d) 237, 131 P. (2d) 1; Helmer v. Superior Court (1920) 48 Cal. App. 140, 191 Pac. 1001, hearing den.; Mountain View v. Southern Pac. R. R. Co. (1934) 1 Cal. App. (2d) 317, 36 P. (2d) 650, hearing den.; Borum v. Graham (1935) 4 Cal. App. (2d) 331, 40 P. (2d) 866; People v. Willert (1939) 37 Cal. App. (2d) 729, 93 P. (2d) 872.

42 Mann v. Scott, supra note 41 (requiring motor vehicles to stop in rear of standing streetcars); Lindebaum v. Barbour (1931) 213 Cal. 277, 2 P. (2d) 161 (requiring motor vehicles to stop at boulevard stop signs); Quinn v. Rosenfeld (1940) 15 Cal. (2d) 486, 102 P. (2d) 317 (prohibiting jay-walking except at right angles to street); Ex parte Snowden (1910) 12 Cal. App. 521, 107 Pac. 724 (fixing maximum speed of motor vehicles); Ham v. Los Angeles County (1920) 46 Cal. App. 148, 189 Pac. 462 (same); Whyte v. Sacramento (1924) 65 Cal. App. 534, 224 Pac. 1008 (forbidding trucks on certain streets); Flynn v. Bledsoe Co. (1928) 92 Cal. App. 145, 267 Pac. 887 (requiring diagonal parking of motor vehicles); Borum v. Graham, supra note 41 (requiring motor vehicles to stop at pedestrian cross-walks when occupied by pedestrians); Mecchi v. Lyon Van \& Storage Co. (1940) 38 Cal. App. (2d) 674, 102 P. (2d) 422, hearing den. (requiring parallel parking of automobiles on city streets other than state highways).

43 (1924) 65 Cal. App. 534, 552, 224 Pac. 1008, 1016.

44 Sispra note 41.

45 Atlas Mixed Mortar Co. v. City of Burbank (1927) 202 Cal. 660, 262 Pac. 334; 
ing or parking outside of business or residence districts, ${ }^{46}$ in specified places, ${ }^{47}$ in front of fire hydrants, ${ }^{48}$ on roadways where there are adjacent curbs, ${ }^{49}$ in snow areas ${ }^{50}$ and on state highways outside of business or residence districts ${ }^{51}$ are linited, restricted or prohibited, as the case may be, by the provisions of the Vehicle Code.

It is also important to note that if parking meter ordinances are sustained under the authority contained in section 11 of article XI, local ordinances and regulations may be superseded at the will of the state legislature by any general laws which may subsequently regulate the field. ${ }^{52}$

As an exercise of the taxing power.

There are three classes of cities in California at this time. These are freeholders' charter cities, pre-1879 special charter cities, and cities organized under the Municipal Corporations Act of 1883 .

Cities organized under sections 6 and 8 of article XI of the state constitution, commonly referred to as freeholders' charter cities, are empowered to exercise varying degrees of municipal home rule. The amendment of 1914 to section 6 of article XI offers this class of cities full control over their municipal affairs, whether or not the charter specifically provides for the particular power sought to be exercised, as long as the power is exercised within the limitations and restrictions contained in the charter. ${ }^{53}$

May a freeholders' charter city, which has plenary power over nunicipal affairs by acceptance of the 1914 tender, enact a parking meter ordinance as an exercise of its power to tax?

Ex parte Daniels; In re Murphy; Pipoly v. Benson, all supra note 41 ; Whyte v. City of Sacramento; Flynn v. Bledsoe Co.; Mecchi v. Lyon Van \& Storage Co., all supra note 42 .

46 CaI. Ver. CODE $\S 582$.

47 Ibid. $\$ 586$.

48 Ibid. \$ 587 .

49 Ibid. § 588 .

50 Ibid. $\$ 589$.

51 Ibid. $\$ 589.5$.

52 Whitmore v. Brown (1929) 207 Cal. 473, 279 Pac. 447; Los Angeles Ry. Corp. v. Los Angeles (1940) 16 Cal. (2d) 779, 108 P. (2d) 430; People v. Willert, supra note 41.

53 Cax. Const. art. XI, § 8; Fragley v. Phelan (1899) 126 Cal. 383, 58 Pac. 923 ; Civic Center Ass'n. v. Railroad Comm. (1917) 175 Cal. 441, 166 Pac. 351; City of Pasadena v. Charleville (1932) $215 \mathrm{Cal}$.384, 10 P. (2d) 745; Butterworth v. Boyd (1938) 12 Cal. (2d) 140, 82 P. (2d) 434; West Coast Adver. Co. v. San Francisco, supra note 7; Kennedy v. Ross (1946) 28 A. C. 582, 170 P. (2d) 904. 
If the installation of parking meters within a city is a "municipal affair", these cities may decide for themselves whether they desire to enact such ordinances. Although the California courts have held that the regulation of traffic, as such, is not a municipal affair, ${ }^{54}$ several cases decided in other jurisdictions have concluded that the enactment of parking meter ordinances constituted an exercise of the municipal taxing power. ${ }^{55}$ In Rhodes $v$. Raleigh $h^{56}$ the court found that the establishment of a system of parking meters was a revenue measure, the meter charge being an excise tax for the privilege of using the parking space. Since freeholders' charter cities in California possess the power to tax for revenue, if enactment of a parking meter ordinance can be considered exercise of the local power to tax, a holding that the regulation of parking through the use of parking meters comes within the scope of the municipal affairs provision of such cities is both logical and possible. ${ }^{57}$ It is undisputed that the power to tax for the purpose of revenue conferred upon a city by charter makes such power a "municipal affair" within the meaning of section 6 of article XI. ${ }^{53}$ Subject only to the himitations of the constitution and the city's charter, the exercise of the power of taxation for municipal purposes is a municipal affair which can be exercised by all freeholders' charter cities which have qualified under section 6 of article XI as amended in $1914 .^{59}$

Those charter cities which have not accepted the tender of the 1914 constitutional amendnient may make and enforce law's and regu-

5. Ex parte Daniels; Pipoly v. Benson; Helmer v. Superior Court; Borum v. Graham, all supra note 41; Atlas Mixed Mortar Co. v. City of Burbank, supra note 45; Lossman v. Stockton (1935) 61 Cal. App. 324, 44 P. (2d) 397; Sandstoe v. Atchison, T, \& S, F, Ry. Co. (1938) 28 Cal, App. (2d) 215, 82 P. (2d) 216,

茨 City of Shreveport v. Brister; Monsour v. City of Shreveport; Rhodes v. Raleigh, all supra note 8; City of Birmingham v. Hood-McPherson Realty Co.; Brodkey v. Sioux City, both supra note 11 .

56 Supra note 8.

57 In an opinion to Senator Randolph Collier, dated April 23, 1946, the California Legislative Counsel reached a contrary conclusion. However, the Counsel indicated that the state legislature would have the authority, by statute, to direct the disposition of net revenues from parking meters to the maintenance of streets and the financing of off-street parking facilities both in chartered municipalities and in cities organized under general laws, since the matter is one concerning the control of traffic and not revenue.

is Security Savings Etc. Co. v. Hinton (1893) 97 Cal. 214, 23 Pac. 3; Ex parte Bruan (1903) 141 Cal. 204, 74 Pac. 780; In re Nowak (1921) 184 Cal. 701, 195 Pac. 402 ; West Coast Adver. Co. v. San Francisco, supra note 7.

69 Keys v. San Francisco (1918) 177 Cal. 313, 173 Pac. 475 ; Storke v. City of Santa Barbara (1925) 76 Cal. App. 40, 244 Pac. 158; Trebilcox v. City of Sacramento (1928) 91 Cal. App. 257, 266 Pac. 1015. 
lations in respect to "municipal affairs" only insofar as a provision for the conduct of those affairs is set forth in the charter. ${ }^{60}$ Thus, in order to determine whether or not these cities have the power to enact a parking meter ordinance by virtue of their control over municipal affairs, reference must be made to the specific contents of each charter. The charters of most cities of this type specifically authorize the imposition of municipal taxes for both revenue and regulatory purposes. Where such authorization is present-assuming that the collection of a fee for the privilege of parking constitutes an exercise of the taxing power-the enactment of a parking meter ordinance would be authorized as a "municipal affair".

Pre-1879 special charter cities must also look to their charter to determine whether or not like power has been conferred upon thein.

However, for the judiciary to hold that the regulation of parking by chartered cities is a valid exercise of their taxing power, it will be necessary to hurdle the constitutional obstacles contained in the federal and state constitutions, i.e., due process, equal protection, privileges and immunities, proper classification for tax purposes, as well as the rights of the public to the free use of the streets. It has been said that a tax measure in order to be valid must lay its burdens uniformly on all members of a class which is to be subject to its burdens. The classification must have some reasonable basis for a differentiation between those who are and those who are not to be taxed. It must be founded on some natural, intrinsic or constitutional distinction; a purely adventitious condition can form no reasonable basis for classification. ${ }^{61}$ The rationale of numerous California cases upholding tax laws as a valid exercise of the municipal power indicates that a carefully drafted parking meter ordinance should meet these requirements. ${ }^{62}$

60 Authorities cited in note 53 , supra.

61 Koenig v. Johnson (1945) 71 Cal. App. (2d) 739, 163 P. (2d) 746.

62 Ex parte Mirande (1887) 73 Cal. 365, 14 Pac. 888; Ex parte Haskell (1896) 112 Cal. 412, 44 Pac. 725; Ex parte Lemon (1904) 143 Cal. 558, 77 Pac. 455 ; Los Angeles v. Los Angeles Etc. Co. (1908) 152 Cal. 765, 93 Pac. 1006; In re Schuler (1914) 167 Cal. 282, 139 Pac. 685; Pacific Ry. Adv. Co. v. Conrad (1914) 168 Cal. 91, 141 Pac. 916; In re Schmolke (1926) 199 Cal. 42, 248 Pac. 244; E. A. Hoffman C. Co. v. Newport Beach (1932) 120 Cal. App. 525, 8 P. (2d) 235; L. A. Brewing Co. v. Los Angeles (1935) 8 Cal. App. (2d) 379, 48 P. (2d) 65; Roth Drug, Inc. v. Johnson (1936) 13 Cal. App. (2d) 720,57 P. (2d) 1022; Continental B. Co. v. City of Escondido (1937) 21 Cal. App. (2d) 388, 69 P. (2d) 181; Auston v. Wilson (1938) 27 Cal. App. (2d) 124, 80 P. (2d) 503; McAdams Oil Co. v. Los Angeles (1939) 32 Cal. App. (2d) 359, 89 P. (2d) 729; Edwards v. City of Los Angeles (1941) 48 Cal. App. (2d) 62, 119 P. (2d) 370; City of San Mateo v. Mullin (1943) 59 Cal. App. (2d) 652, 139 P. (2d) 351. 
If installation of the parking meter is upheld as a valid exercise of the municipal tax power rather than as an exercise of the police power, the result is very different. As already discussed herein, fees collected from a police regulation must be expended in maintenance of the regulatory device, or reasonably related activities. This restriction would not be attached to funds acquired for a revenue purpose. ${ }^{63}$ Thus the proceeds acquired by use of parking meters would be available for any municipal purpose.

Unless authorized by general law, cities incorporated under the provisions of the Municipal Corporations Act ${ }^{64}$ possess only those powers specified in that act for cities of the various classes established. ${ }^{65}$ No general power to levy municipal taxes is granted. Section 862.12 of the Municipal Corporations Act empowers sixth-class cities "to license, for the purpose of revenue and regulation, all and every kind of business authorized by law and transacted and carried on in such city . . . A A similar provision is contained in section 764(10) relating to cities of the fifth class. Although it might be contended that the imposition of a fee for the privilege of securing a parking space amounts to a "license", inasmuch as the regulation of parking is not within the normal concept of "business", the parking meter probably cannot be adopted as exercise of the taxing or licensing powers of cities incorporated under the Municipal Corporations Act.

\section{The rights of abutting property owners.}

Assuming that both charter cities and Municipal Corporations Act cities have the power to enact parking meter ordinances, whether it be under the police power or taxing power, is there any reason to believe that the exercise of such power might be unconstitutional? The California courts have often stated that the owners of property abutting on a street possess not only the right to use the street in common with other members of the public but also a private right, or easement of access, for the purpose of ingress or egress to and from their property. The Califorma courts have been solicitous in protecting the rights of an abutting property owner. ${ }^{66}$ However, the Cali-

63 Rothschild v. Bantel (1907) 152 Cal. 5, 91 Pac. 803; Los Angeles v. Los Angeles Etc. Co.; McAdams Oil Company v. Los Angeles, both supra note 62.

64 CaL. Gen. Laws (Deering 1944) Act 5233.

65 San Mateo v. Railroad Comm., supra note 41 ; Peppin, Municipal Honne Rule in California (1942) 30 CALIF. L. REv. 272, 315.

${ }^{66}$ Eachus v. Los Angeles Etc. Ry. Co. (1894) 103 Cal. 614, 37 Pac. 750; Guerkink v. City of Petaluma (1896) 112 Cal. 306, 44 Pac. 570; O'Connor v. Southern Pac. R. R. 
fornia supreme court in discussing the nature of these rights in People v. Ricciard $i^{6 \pi}$ said, "... it is only the value of, and the damage to, the property itself, which may be considered ...." Moreover, the court flatly stated that it has been held in this state that an abutting owner has no right to compensation because traffic has been diverted away from his property. The only California case dealing with a situation similar to the installation of a parking meter on the sidewalk is that of Williams v. Los Angeles Ry. Co..$^{08}$ where the railway company erected a twenty-foot switch tower approximately five feet square at the top on the public sidewalk in front of plaintiff's property. The court allowed the property owner compensation on the ground that the view to his property, a business location, was obstructed. Certainly no comparable argument can be made regarding a parking meter.

The court in Rose v. State of Calif. ${ }^{60}$ indicated that reasonable regulation was proper and that no compensation was allowable:

"... the easement of access is as a matter of law peculiar to the individual owner, and an unreasonable interference with such an easement is an injury necessarily different from the injuries suffered by the general public.... The right extends to a use of the highway for purposes of ingress and egress to his property by such modes of conveyance and travel as are appropriate to the highway and in such manner as is customary or reasonable." (Italics supplied.)

When discussing the restrictions involved in the case of McCandless v. City of Los Angeles, ${ }^{\text {in }}$ the court said:

"We arrive at this conclusion [that plaintiff had a cause of action in alleging damage to his property by the construction of a street subway upon which it abutted] without intimating, as counsel for the defendant apprehend, that the construction of a lamp-post or an

Co. (1898) 122 Cal. 681, 55 Pac. 688; Brown v. Board of Supervisors (1899) 124 Cal. 274, 57 Pac. 82 ; Smith v. Southern Pacific R. R. Co. (1905) 146 Cal. 164, 79 Pac. 868; Williams v. Los Angeles Ry. Co. (1907) 150 Cal. 592, 89 Pac. 330; Wilcox v. Engebretsen (1911) 160 Cal. 288, 116 Pac. 750; Lane v. San Diego Elec. Ry. Co. (1929) 208 Cal. 29, 280 Pac. 109 ; McCandless v. City of Los Angeles (1931) 214 Cal. 67, 4 P. (2d) 139; Rose v. State of California (1942) 19 Cal. (2d) 713, 123 P. (2d) 505; People v. Ricciardi (1943) 23 Cal. (2d) 390, 144 P. (2d) 799; People v. Gianni (1933) 130 Cal. App. 584, 20 P. (2d) 87; City of Stockton v. Marengo (1934) 137 Cal. App. 760, 31 P. (2d) 467; McCandless v. City of Los Angeles (1935) $10 \mathrm{Cal}$. App. (2d) 407, 52 P. (2d) 545.

6r' (1943) 23 Cal. (2d) 390, 396, 144 P. (2d) 799, 802.

68 (1907) 150 Cal. 592, 89 Pac. 330.

69 (1942) 19 Cal. (2d) 713, 727, 123 P. (2d) 505, 514.

70 (1931) 214 Cal. 67, 72, 4 P. (2d) 139, 141. 
electrolier in front of private property would constitute a special and peculiar and substantial impairment of a private right."

From the above discussion it would seem that any interference with the common-law rights of a property owner produced by the installation of parking meters would not be unreasonable. Certainly it cannot be said that his right of ingress and egress is denied. Nor is the view to his property obstructed. Either the property owner or anyone else of the general public may pay the designated fee and secure a parking space. This conclusion is also fortified by the fact that although the rights of the abutting property owner have been discussed in practically every case dealing with the validity of parking meter ordinances, in only one jurisdiction was it held that these rights had been seriously interfered with, so that the ordinance was invalid; this result depended largely upon the wording of the instrument dedicating the land to the city for use as a public street. This case illustrates, however, that where a private dedication is made to a city, use made of the land so dedicated must be consistent with the purpose of the dedication. ${ }^{71}$

Only an express prohibition or restriction contained in a deed or grant should preclude the mumcipality from regulating traffic by the use of parking meters; however, cities contenplating installation of parking meters should examine any deeds granting to the city the land on which the streets are constructed in order to avoid future difficulties.

\section{Use of funds.}

If parking neter ordinances are sustained as a valid exercise of the police power conferred upon cities by section 11 of article XI, it follows that the measure must be a regnlatory rather than a revenue one. ${ }^{i 2}$ There is reason to believe, however, that the California courts will sustain any use of funds derived from the imposition of fees for the privilege of parking which is substantially related to the over-all problem of traffic regulation and control. This is indicated by the language contained in DeAryan v. City of San Diego ${ }^{73}$ wherein the court approved the use of receipts from parking fees to defray the expenses of installation, operation and control of the parking meters

71 Slavich v. Hamilton (1927) 201 Cal. 299, 257 Pac. 60; San Francisco v. Linares (1940) 16 Cal. (2d) 441, 106 P. (2d) 639.

72 Cooley, loc. cit. supra note 23.

T3 Supra note 38. 
and parking spaces, as well as for the control of traffic in general, including the cost of painting lines and signs, maintaining mechanical traffic signals and other expenses of regulating traffic and enforcing traffic regulations. The court said:

"A reasonable variance must necessarily be allowed ... [ [where the cost is based upon estimates], so long as the object of the ordinance is the regulation of traffic and not the raising of revenue, and as long as any possible surplus or profit is both incidental and not disproportionate to the cost and scope of the regulation thus carried into effect." 74

As long as the primary purpose of the ordinance is to regulate and not to raise revenue, the mere fact that the receipts from fees exceed the cost of regulation is not objectionable. ${ }^{75}$

In view of the discussions of this problem by the California courts, it would appear that revenues derived from the installation of parking meters may be utilized for any purpose which is substantially connected with the problem of traffic control and regulation, including traffic enforcement, traffic engineering, traffic circulation, purchase of off-street parking facilities, signalization, street signs, trafficenforcement officers' salaries, as well as the purchase, installation, supervision, protection, inspection, maintenance and operation of the parking meters themselves. The use of parking meter funds for the construction or maintenance of city streets or for the provision of ornamental lighting facilities is, however, of questionable legality. The use of parking meter proceeds for these purposes will, of course, free funds for other purposes.

Inasmuch as the purposes for which parking meter funds may be expended may be limited to those specified above, the establishment by ordinance of a special fund appears warranted. Since general funds may be utilized for any municipal purpose, an unfavorable presumption is created by treating them as receipts allocated to general funds, even though they are not actually used for general purposes.

$$
\text { * * * }
$$

The decisions of the courts sustaining the use of parking meters and the concomitant imposition of a fee for the privilege of parking

74 Ibid. at 351, 170 P. (2d) at 485; cf. Urban v. Riley (1942) 21 Cal. (2d) 232, 236, 131 P. (2d) 4, 6 .

75 City of Madera v. Black (1919) 181 Cal. 306, 184 Pac. 397; In re Higgins (1920) 50 Cal. App. 533, 195 Pac. 740; Glass v. City of Fresno (1936) 17 Cal. App. (2d) 555, 62 P. (2d) 765. 
are understandable when considered in the light of economic and social necessity, as well as the duty of local governments to provide access to and use of the market places by the citizenry.

The increased use of the automobile as a means of transportation has resulted in a tremendous need for parking facilities, which has not been met by private capital. The heart of every city of any considerable size is strangling from the pressure exerted by modern traffic conditions. This pressure will ease, and decentralization will be retarded, by providing for adequate off-street parking facilities. There is no lack of authority to meet this need ${ }^{76}$ but there is lack of public funds. Private venture capital will follow when experience demonstrates the feasibility of such projects. Local governments will have to take the risk of initial experiments. The funds derived from the parking meter appear to provide the most expedient method of financing the off-street parking facilities which secure the maximum economic and social advantage from the limited space available in congested business areas; the installation, therefore, of parking ineters in seventy-two California cities is to be viewed with approval.

${ }^{6}$ The creation of automobile parking districts empowered to acquire, construct, operate and maintain automobile parking facilities is authorized by the Automobile Parking District Act of 1941 (Cal. Stats. 1941, p. 1312, as amended, 2 CAL. Gen. LAws [Deering, 1944] Act 5131.1), the Second Automobile Parking District Act of 1941 (Cal. Stats. 1941, p. 2802, 2 CaL. GEN. Laws [Deering, 1944] Act 5132.2), and the Vehicle Parking District Act of 1943 (Cal. Stats. 1943, p. 2859, as amended, 2 CAx. Ger. Laws [Deering, 1944] Act 5131.3). Cal. Stats. 1927, p. 1413, 2 CaL. GeN. Laws (Deering,1944) Act. 5131a authorizes local governmental agencies to use public property for the establishment and operation of parking facilities when such property is not otherwise needed for other public purposes. Section 1238.1 of the Code of Civil Procedure authorizes cities to acquire real property for the purpose of providing parking facilities. 